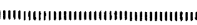

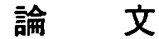

UDC $669.162 .26: 669.162 .251 .244: 662.614: 66.012 .23: 669.162 .012 .24$

高炉の低燃料比操業についで*

$$
\begin{aligned}
& \text { 研野 雄二***.楯岡 正毅**. 須賀田正泰** } \\
& \text { 山口 一成**. 久米 } \text { 正一**.山口 一良** } \\
& \text { 安倍 勲*** }
\end{aligned}
$$

\title{
Operation of Blast Furnace at the Condition of Low Fuel Rate
}

Yuji Togino, Masatake Tateoka, Masayasu Sugata,

Kazusige Yamaguchi, Shoichi Kume, Kazuyoshi Yamaguchi, and Isao $\mathrm{ABE}$

Synopsis:

At No. 3 blast furnace of Kimitsu Works, a test operation was planned to foresee the lower limit of fuel rate (the target was $430 \mathrm{~kg} / \mathrm{t}-\mathrm{Pig}$ ) mainly by controlling the softening-melting zone in the furnace. As a result of the operation, the new record of fuel rate $431 \mathrm{~kg} / \mathrm{t}-\mathrm{Pig}$ was attained in March, 1975.

Based on the result of the test operation, the technique to lower fuel rate was investigated and the lower limit of fuel rate to be attained in next 10 years (about $400 \mathrm{~kg} / \mathrm{t}-\mathrm{Pig}$ ) was estimated by use of mathematical model. The technique for attaining this fuel rate is mainly in the improvement of raw material properties.

\section{1. 緒言}

高炉燃料比は年々めざましい低減の成果をあげ，日本 鉄鋼業の国際競争力の 維持に大きな 役割を果してきた が, 昭和 48 年末の石油価格高騰後の省エネルギの要請 の強まりは，高炬燃料比低減への努力をさらに高めるも のとなつた。

君津 3 高炉は原料, 設備, 作業, 操業の技術の相乗効 果としてすぐれた操業成績を残してきたが，高炉解体調 査の結果, 炉内現象の理解が深まるとともにその解析を 進め, とくに軟化融着帯の存在形態が高炉の操業成績に 大きな影響を与えるものとして，これを制御するために 数多くの試みをムーバプルアーマー（以下 MA と略す） の利用を主体に行ってきた1)。それらの結果を集約する 形として, 君津 3 高炉において 低燃料比試験操業計画 （目標 $430 \mathrm{~kg} / \mathrm{t}-\mathrm{Pig}$ ）を立案し, 昭和 50 年 3 月に月間 平均燃料比 $431 \mathrm{~kg} / \mathrm{t}-\mathrm{Pig}$ の新記録を達成すると同時に, 低然料比操業についてのいくつかの知見を得ることがで きた。

本報文においては，低燃料比操業へのアプローチと操 業実績を示すとともに，今後の燃料比低減の技術的手段
についても検討し, 実際に今後 10 年間程度で達成すべ き燃料比のレベルについて試算した。

\section{2. 燃料比低減対策の検討}

\section{$2 \cdot 1$ 従来から実施されている燃料比低減対策}

然料比を低減させるために従来から実施されている対 策としては，入熱量の増加，所要熱量の減少，損失熱の 減少に関する種々のものがあるが，昭和 49 年 10 月の 君津 3 高炉実績値（Table 1 参照）をべースにして, 従 来の対策の限界と燃料比に及ぼす効果について検討し た. 項目ごとに個条書きすると次のようになる.

送風温度 : $+10^{\circ} \mathrm{G}$ (然料比 $\left.-0.8 \mathrm{~kg} / \mathrm{t}-\mathrm{Pig}\right)$

送風湿度 : $-1.0 \mathrm{~g} / \mathrm{Nm}^{3}$-Blast $(-0.8 \mathrm{~kg} / \mathrm{t}-\mathrm{Pig})$ コークス灰分 : $-1.0 \%(-10.0 \mathrm{~kg} / \mathrm{t}-\mathrm{Pig})$

焼結鉱平均粒度 : $-1.0 \mathrm{~mm}(-1.0 \mathrm{~kg} / \mathrm{t}-\mathrm{Pig})$

焼結鉱中 $\mathrm{FeO}$ 含有量 : $-1.0 \%(-4.4 \mathrm{~kg} / \mathrm{t}-\mathrm{Pig})$ また，羽口に耐火断熱リングを挿入することにより約 $25^{\circ} \mathrm{C}$ の送風温度低下を防止できる $(-2.0 \mathrm{~kg} / \mathrm{t}-\mathrm{Pig})$.こ のほかの項目については, スラグ量は減少できず, 重油 比，炉頂圧力，塊成鉱比はほぼ最大值を維持しており， 石灰石は使用していない（還元鉄は低減対策からは除い

* 昭和 53 年 4 月本会講演大会にて発表 昭和 53 年 6 月 12 日受付 (Received June 12, 1978)

** 新日本製鉄(株)君津製鉄所 (Kimitsu Works, Nippon Steel Corp., 1 Kimitsu Kimitsu 299-11)

*** 新日本製鉄 (株) 本社 (Nippon Steel Corp.) 
て考える)，また溶銑中 $\mathrm{Si}$ 含有量は，高炉の熱レベルを 維持するためには現状では低下できず，溶銑中 Mn 含 有量の低下は効果が小さい。

以上の対策を可能な範囲に実施した場合の効果を単純 に合計すると燃料比低隇量は $20 \mathrm{~kg} / \mathrm{t}-\mathrm{Pig}$ となり，昭和 49 年 10 月の君津 3 高炉実績値を基準にすると,燃料比 は $435 \mathrm{~kg} / \mathrm{t}-\mathrm{Pig}$ であり,さらに低減をはかるためには上 述以外の対策，すなわち，ガス利用率（以下 $\eta$ co と略 す）の向上，炬体放散熱低減が必要となる。

\section{2 軟化虽着带制御をベースとした燃料比低隇対策}

解体高炉の炉内調查結果によつて, 軟化融着帯が高炉 操業を支配する重要なポイントであることが判明した。 そこで然料比を低減させるための軟化融着帯の制御方法 について，数学モデルを用いて検討した.

\section{$2 \cdot 2 \cdot 1$ 軟化融着帯形状とガス流れ}

軟化融着帯形状の高炉操業に与える影響を検討するた めに，軟化融着帯形状が設定されたとき，各ュークスス リットのガス流分配割合と塊状帯炉壁部のガス圧力分布 を推定するモデルを開発し報告した6)。この前報によれ ば, 高炉の燃料比低减対策としての軟化融着帯形状は, 内側が炉中心側に近い形状を指向すべきであると考兄ら れ，その理由として次の 3 項目が挙げられる.

(1)圧力損失は增加するが, 融着帯頂層变動に対してガ ス流があまり変わらない（安定性）。

(2)外側形状が怇中心側にあるため，炉上部では塊状帯

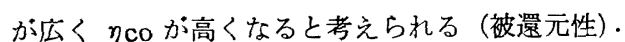

(3)内側形状が炉中心側にあるため, 炉下部で炉内ガス が中心部を流れ，炉下部の炉体からの放散熱が低隇する と考えられる (熱効率).

\section{$2 \cdot 2 \cdot 2$ 軟化融着带位置の検討}

軟化融着帯位置の高炬操業に与光る影響を検討するた めに，高炬を円筒とみなし半径方向に分布のない均一系 としたとき，高炉の炬内温度分布を推定する化学工学的 モデル（熱収支, 物質収支に還元反応速度, 伝熱速度を

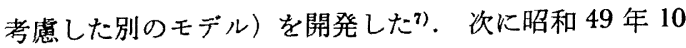
月の君津 3 高炬の実績值をべースにこのモデルを適用し た結果を示す。

Fig. 1 亿釷石の溶け落ち温度を変えたときの，融着開 始, 滴下開始位置, 羽ロレペルの溶銑㳯温度, 溶銑中 $\mathrm{Si}$ 含有量の変化を示す. 溶け落ち温度が高くなるにつ れ, 融着滴下開始位置は低下し, 羽ロレベルの溶銑温度 が高くなり，溶銑中 $\mathrm{Si}$ 含有量の低下することがわか る.したがつて高炉の熱レペルを溶銑温度とした場合， 溶け落ち温度が高くなると，溶銑温度を一定とするため に鉱石とコークスの装入割合（以下 $\mathrm{O} / \mathrm{C}$ と略す）を上

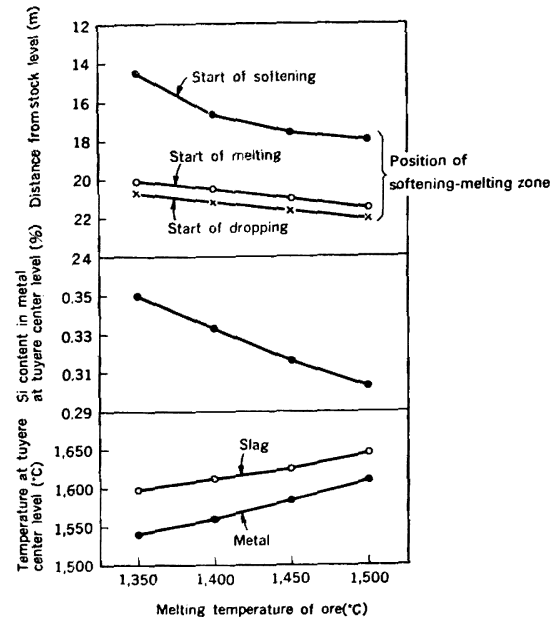

Fig. 1. Effect of melting temperature of ore on $\mathrm{Si}$ content in metal and temperature of melt at tuyere center level.

昇させ，溶銑中 $\mathrm{Si}$ 含有量の低下と合わせて燃料比低減 が期待できるまた，融着開始位置の低下そのものが塊 状帯を広げることになり， $\eta$ co 向上による燃料比低減む 期待できる.

\section{$2 \cdot 2 \cdot 3$ 炉下部円周バランス制御}

軟化融着帯の位置が低下してくると, 羽ロレベルにお ける融着带根部の溶解能力の面から制約が出てくる.こ のとき，炬下部融着帯形状が均一化されていること，す なわち円周バランスがとれていることが，位置の低下を より極限に近づけるための前提条件となる．円周バラン ス制御としては羽口ごとのコークス消費量を均一化させ る方法が举げられ，その方法として羽ロごとの送風量， 酸素量, 送風湿度, 重油量などの調整が考えられるが, 実際上設備的に重油量の調節による制御が最も容易であ る. Fig. 2 に羽口重油量変化に伴らコークス消費量の変 化の試算結果を示すが, 羽口重油量 $\pm 2001 / \mathrm{h}$.本により 干7\% のコークス消費量調節効果のあることがわかる.

以上述べたような軟化融着带制御を実施することによ $\eta, \eta$ co の向上, 炬体放散熱低減が期待でき, 燃料比 $430 \mathrm{~kg} / \mathrm{t}-\mathrm{Pig}$ が達成可能と判断した.

\section{3. 低燃料比試験操業計画}

前節で述べた軟化融着帯制御を望行に移すため低燃料 比試験操業の計画を立案した，計画概要を以下に示す.

\subsection{MAの使用計画}

㳄化融着帯形状を制御する場合に，最も効果的な手段 は半径方向の $\mathrm{O} / \mathrm{C}$ 分布を調整可能な $\mathrm{MA}$ の使用であ 


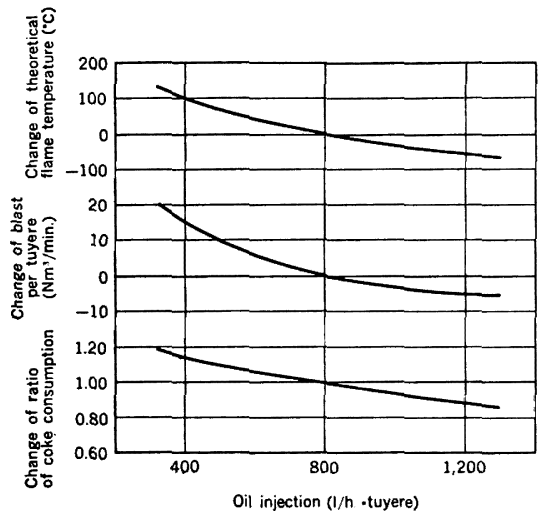

Fig. 2. Effect of oil injection on coke consumption of each tuyere.

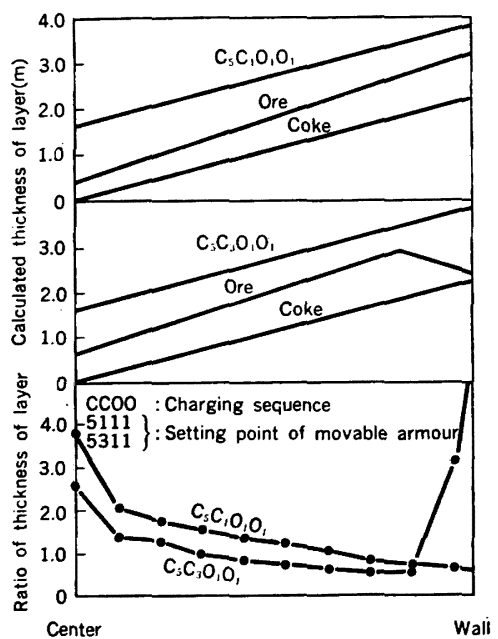

Fig. 3. Calculated thickness ratio of coke and tion ore layer.

る．前述した軟化融着帯形状を指向するためには，炉周 辺部の O/C をある程度高く保ち，かつ炬中心と炉壁の 間の中間部の $\mathrm{O} / \mathrm{C}$ を高くしていく必要がある. CCOO の4パッチで1チャージを構成する装入スケジュールに おいて，MA の位置(ノッチと称する) をパッチごとに 調整する使用方法1) のノッチによる变化の推定計算結果 をFig. 3 に示す. 計算には田阪 ら²) の装入物落下軦跡 の式をるとにした.

Fig. 3 上り，炉周辺部の $\mathrm{O} / \mathrm{C}$ をある程度高く保つた めにはノッチ構成を 5111 よりも 5311 とすることが必 要であり，さらに炉中間部の $\mathrm{O} / \mathrm{C}$ を高くするためには 多少，炉周辺部を儀牲にしても 2 ハッッ目のコークス， ッチを若干小さくする（例えば 52.511 など）必要が
ある。この観点から事前に操業試験を実施し，ノッチ構 成は 5311 をべースに 2 バッチ目のコークスノッチを調 整することにした。

\section{2 焼結鉱性状および配合割合}

装入鉱石の溶け落ち温度を高める方法として，焼結鉱 については西田ら゙）の実験結果より塩基度 $\left(\mathrm{CaO} / \mathrm{SiO}_{2}\right)$ を1.5〜1.8 に保つ必要がある。また焼結鉱配合割合に ついては，酸性ペレットを対象とする場合，斧4) の実験 結果拉上び操業試験結果 $\left(\mathrm{CaO} / \mathrm{SiO}_{2}=1.5 \sim 1.6\right.$ の焼結 鉱とマルコナペレットを用いた）より，焼結鉱配合割合 の高いほらが装入鉱石の溶け落ち温度が高くなる。

以上の検討をもとに，焼結鉱の塩基度を 1.6 , 焼結鉱 配合割合は $95 \%$ で計画した．またこのほかに，焼結鉱 性状として焼結鉱の常温強度を保つ範囲で $\mathrm{FeO}$ 含有量 を低下させる（目標 $6 \%$ ）ことを試験操業中に実施する 計画とし, 高炉の通気性を阻害しない範囲で焼結鉱の平 均粒度を低下させる操業試験を事前に実施し，18mm 程 度を目標とした。

\section{3 炉下部円周バランス制御}

羽ロごとの重油量を調節しょークス消費速度の円周方 向均一化をはかることにより，4本の出銑口から流出す る溶銑中 $\mathrm{Si}$ 含有量, 溶銑温度のばらつきを減少させる 円周バランス制御法の効果を，事前に操業試験を行つて 把握した。

事前操業試験は 2 段階に分け，第 1 ステップでは羽口 支管風量のばらつきによる円周バランス崩れを矯正する ために，風量の多い羽口の重油量を増加させコークス消 費速度を均一化する方法を，第 2 ステップでは円周方向 の $\mathrm{O} / \mathrm{C}$ 分布の仿らつきによる円周バランス崩れを矯正 するために，第1 ステップを実施した状態で，さらに未 還元鉱石の羽口への落下（生鉱落ちと称する）の状況を 監視しながら重油量を調整する方法を実施した．結果を Fig. 4 に示すが，第 2 ステップまで実施することによ $\eta, 4$ 本の出銑口間の溶銑中 $\mathrm{Si}$ 含有量, 溶鉄温度のぱ らつきが減少し効果が確認できた。

な和実施に当たつては，羽口ごとの理論然焼温度の大 幅な変化を避けるため, 重油量は $\pm 200 \mathrm{l} / \mathrm{h}$ ·本の調節範 囲にとどめることにした。

\section{4 操業条件の整備および操業管理基準の設定}

㳄化融着帯制御による燃料比低減をささえるべース操 業条件の整備として，従来から実施されている燃料比低 減対策の完全実施のほかに, 羽ロレベルで発生するガス 量（以下ボッシュガス量と称する）と溶銑トン当たり所 要熱量の関係の解析結果から, 所要熱量が極小となるレ ヘルとしてポッシュガス量を $8700 \mathrm{~N} \mathrm{~m}^{3} / \mathrm{min}$. に設定し 


\begin{tabular}{|ll|c|c|}
\hline \multicolumn{2}{|c|}{ Test period } & $\begin{array}{c}\text { R of Si content } \\
\text { in pig iron (\%) }\end{array}$ & $\begin{array}{c}\text { R of pig temperature } \\
\text { ('C) }\end{array}$ \\
\hline Base period & (30, Nov. 3, Dec. 1974) & 0.088 & 24.5 \\
Period of 1st step & $(5 \sim 9$, Dec. 1974) & 0.070 & 11.6 \\
Period of 2nd step & $(11 \sim 15$, Dec. 1974) & 0.075 & 6.0 \\
\hline
\end{tabular}

(R means range (max. $-\min$.$) of each tap hole.)$

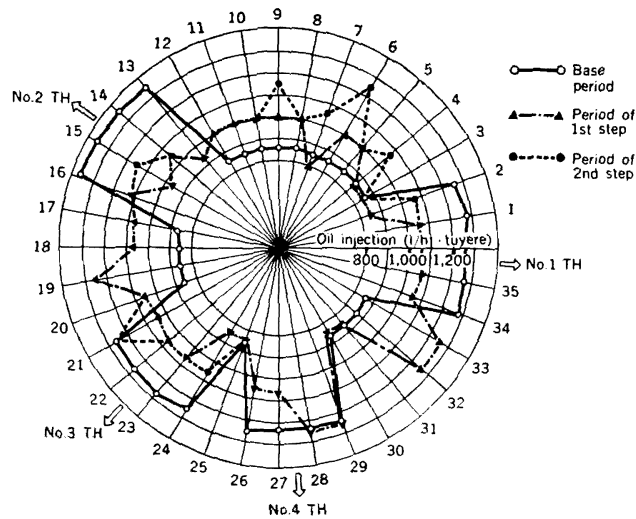

Fig. 4. Circumferential epualization of Si content in metal and temperature of melt by controlling oil injection of each tuyere (Results of preliminary test)

た. また，羽ロへの耐火断熱リング捚入の効果は，事前 に操業試験を実施し, 羽口泠却水の給排水温度差が 5.1 ${ }^{\circ} \mathrm{C}$ 減少し, 送風温度換算で $24.1^{\circ} \mathrm{C}$ 上昇を確認した.

次に, 低燃料比試験操業を実施するための操業管理基 準を以下のように設定した。

(1)コークスの常温強度 : $\mathrm{DI}^{150}>81.5 \%$

(2)焼結鉱の常温強度 : $\mathrm{SI}>88 \%$

(3)高炉の熱レペル：溶銑中 $\mathrm{Si}$ 含有最は，コークス灰 分によつて同一溶銑温度でも異なるため, 試験期間中の コークス灰分に合わせて $0.3 〜 0.35 \%$ (たたし溶銑温度 $\left.1500 \sim 1520^{\circ} \mathrm{C}\right)$ に設定した.

(4)限界炬頂ガス温度 : 前述した化学工学的モデル7)に より限界炉頂ガス温度を計算し，炉頂ガス温度が限界よ り低下した場合は送風量と酸素量を置換してボッシュガ ス量を増加させるアクションを行う。

(5)根部溶解能力 : $B G^{0,7} \times T f=$ 一定の関係を保つよう に操業条件を調整する $(B G$ : 溶銑 $\mathrm{t}$ 当たりボッシュガス 量, $T f$ : 羽口前理論燃焼温度).

Fig. 5 に主要全国高炉の $B G$ と $T f$ の関係を示す. ガスから炉壁への熱伝達係数を求める葛岡の式5)

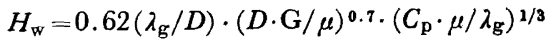

たたし $H_{\mathrm{w}}$ ：ガスから炬壁への熱伝達係数 $(\mathrm{kcal} /$ $\left.\mathrm{m}^{2} \cdot \mathrm{h} \cdot{ }^{\circ} \mathrm{C}\right)$

$D$ : 反応管径 $(\mathrm{m})$

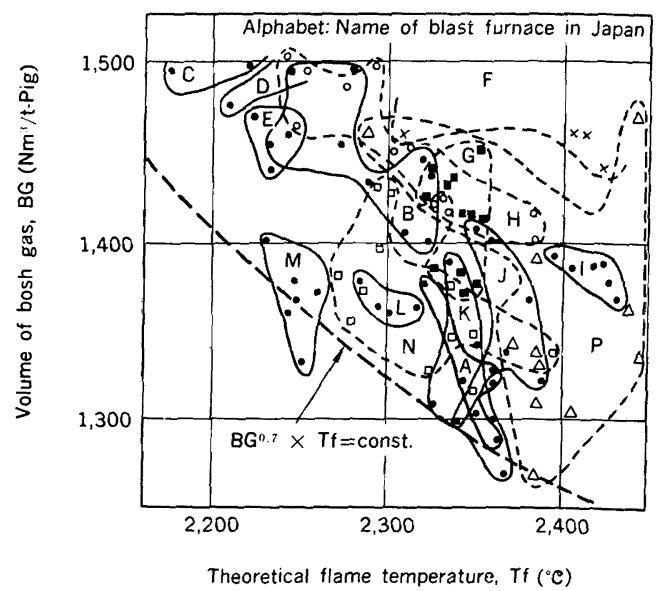

Fig. 5. Relation between theoretical flame temperature and volume of bosh gas (actual data in operation).

$$
\begin{aligned}
& \lambda_{\mathrm{g}}: \text { ガス熱伝導率 }\left(\mathrm{kcal} / \mathrm{m} \cdot \mathrm{h} \cdot{ }^{\circ} \mathrm{C}\right) \\
& G: \text { ガスの質量速度 }\left(\mathrm{kg} / \mathrm{m}^{2} \cdot \mathrm{h}\right) \\
& \mu: \text { ガスの粘度 }(\mathrm{kg} / \mathrm{m} \cdot \mathrm{h}) \\
& C_{\mathrm{p}}: \text { ガスの比熱 }\left(\mathrm{kcal} / \mathrm{kg} \cdot{ }^{\circ} \mathrm{C}\right)
\end{aligned}
$$

を用いると，ガスから根部への伝熱量は根部単位面積当 たり $H_{\mathrm{w}} \cdot\left(T f-T_{\mathrm{R}}\right) \quad\left(T_{\mathrm{R}}\right.$ は根部温度 $)$ となり， $T_{\mathrm{R}}=$ 一 定とすると $H_{\mathrm{w}} \cdot T f$ に比例する。 よつて羽ロレベルにお ける根部溶解能力を $B G^{0.7 . T f}$ で代用することができ Fig. 5 の下限ラインは $B G^{0.7} \cdot T f=$ 一定の線に一致する ことから，低ボッシュガス量のときは，ガスから根部へ の伝熱律速で操業が行われていると解釈できる.

(6)羽口前理論然焼温度 : $T f>2300^{\circ} \mathrm{C}$ (君津 3 高炉の 実績)

なお，これら操業管理基準設定と併行して設備面でと くに高炉検出端の総点検整備を実施して管理の徹底をは かり，事故体風による然料比上昇防止につとめた。

\section{4. 低燃料比試験操業結果}

試験操業計画にしたがつて操業を実施し，昭和 50 年 3 月に月間平均然料比として $431 \mathrm{~kg} / \mathrm{t}-\mathrm{Pig}$ を達成し た. Table 1 に操業成績を示す.

\section{$4 \cdot 1$ 操業経過の概要}

Fig. 6 に昭和 49 年 10 月から 50 年 3 月までの月別 操業成績の推移を示す。これにもとつ゚いて 50 年 3 月に 至るまでの操業経過につき以下に述べる。

まず MA の使用については，計画ど扣り5311 のノ ッチ構成を基本とし，52.511 を併用しながら操業を 行つた，炬頂圧力は設備能力最大の $2.3 \mathrm{~kg} / \mathrm{cm}^{2}$ を使用 
Table 1. Operating results of base period, of test period and at boundary condition.

\begin{tabular}{|c|c|c|c|c|c|}
\hline Item & Unit & $\begin{array}{l}\text { Actual results } \\
\text { Oct. } 1974\end{array}$ & $\begin{array}{l}\text { Actual results } \\
\text { Mar. } 1975\end{array}$ & $\begin{array}{l}\text { Effect of factor } \\
\text { on fuel rate*** }\end{array}$ & $\begin{array}{l}\text { Estimated results } \\
\text { at boundary } \\
\text { condition }\end{array}$ \\
\hline $\begin{array}{l}\text { Production } \\
\text { Coke rate } \\
\text { Oil rate } \\
\text { Fuel rate } \\
\text { O/C } \\
\text { Blast volume } \\
\text { Oxygen enrichment } \\
\text { Blast temperature } \\
\text { Blast humidity } \\
\text { Top gas pressure } \\
\text { Slag volume } \\
\text { Pig temperature } \\
\text { Si content in pig iron } \\
\text { Top gas temperature } \\
\text { CO gas utilization } \\
\text { Coke ash content } \\
\text { Ratio of sinter in burden } \\
\text { Ratio of pellet in burden } \\
\text { FeO content in sinter } \\
\text { Mean size of sinter } \\
\text { Solution loss carbon } \\
\text { Ratio of C reduction } \\
\quad \text { " H " } \mathrm{H}_{2} \\
\text { " } \\
\text { Heat loss " } \\
\text { Refractory tuyere rings } \\
\text { Melting temperature of ore } \\
\text { Reducibility of ore }\end{array}$ & 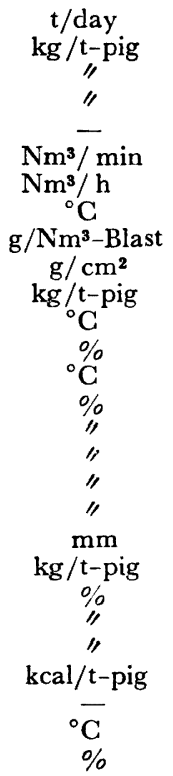 & $\begin{array}{c}10091 \\
379.4 \\
75.3 \\
454.7 \\
4.297 \\
6713 \\
12735 \\
1275 \\
10.7 \\
2282 \\
321 \\
1514 \\
0.35 \\
124 \\
49.8 \\
11.7 \\
92.3 \\
7.7 \\
6.82 \\
20.37 \\
91.9 \\
31.1 \\
10.7 \\
58.2 \\
165 \times 10^{3} \\
\text { Old } \\
1400 \\
67\end{array}$ & $\begin{array}{c}9533 \\
364.7 \\
65.8 \\
430.5 \\
4.474 \\
6374 \\
5476 \\
1316 \\
7.1 \\
2279 \\
323 \\
1508 \\
0.30 \\
107 \\
51.9 \\
12.0 \\
92.5 \\
7.5 \\
7.04 \\
19.13 \\
97.7 \\
33.0 \\
9.7 \\
57.3 \\
117 \times 10^{3} \\
\text { New } \\
1400 \\
70\end{array}$ & $\begin{array}{l}-3.3 \\
-2.9 \\
- \\
+0.5 \\
-3.5 \\
-12.6 \\
+3.0 \\
- \\
+1.0 \\
-1.2\end{array}$ & 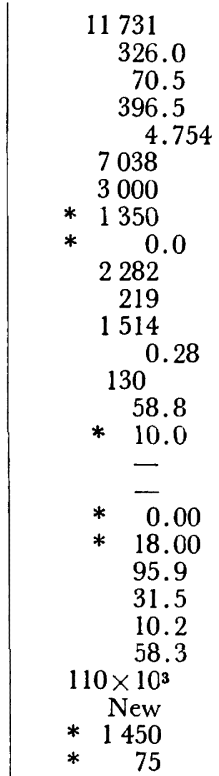 \\
\hline
\end{tabular}

* Data set at boundary condition ** Actual difference of fuel rate

*** Data of Mar. 1975 as compared with Oct. 1974

し，送風量減少により炉内ガス流速は 10 月の $3.55 \mathrm{~m} / \mathrm{s}$ より 3 月の $3.15 \mathrm{~m} / \mathrm{s}$ まで低下した。焼結鉱粒度は 2 次 クラッシャーセッティング調整により 18〜20 mm に維 持し， $\mathrm{FeO}$ 含有量は6〜7\% と低目で推移した。 また 絖結鎕合比は 92.5〜94\% とほぼ計画どおりの值を維 持した。これらの対策の結果， $\eta$ co は 10 月の $49.8 \%$ か ら 2 月の $52.0 \% ， 3$ 月の $51.9 \%$ まで上昇した。

送風温度については，並列操業における後行熱風炉の 冾風弁全閉による冷風混入防止と，燃焼初期の過剩空 気量の減少による燃焼制御改善の対策の結果，10月の $1275^{\circ} \mathrm{C}$ より 3 月には $1313^{\circ} \mathrm{C}$ まで上昇した. 高炉の熱 レベルは，溶銑温度を $1510 \pm 5^{\circ} \mathrm{C}$ に調整し Si 含有量 は $0.31 〜 0.37 \%$ の間におさまつた。

Table 1 に然料比低隇に奇与した要因の効果の解析を 行つているが，従来から実施されている対策たけでは足 りず，ガス利用率の向上，炬体放散熱低減が燃料比低減 に大きく寄与している.

\section{2 軟化融着带形状の検出}

前述した融着帯モデル6)を発展させ，高炉の炉壁部高 さ方向に設置されている圧力（シャフト圧力と称する） の実測値に合うように, 軟化融着带形状を曲線で近似し て推定した結果が Fig. 7 である.これによると，I期
間から而期間に移行するにしたがつて軟化融着帯内側形 状が炉中心側に近づき塊状带体積が広がり, $\eta_{\text {co }}$ の向 上，炉体放散熱の低下がみられた。

Fig. 8 は高炉シャフト上部の装入物中半径方向ガス温 度分布1) と MA ノッチの関係であるが，2バッチ目の コークスノッチの変更により, 炉周辺部および中間部の ガス温度の変化しているようすがわかる.

これらのモデルによる推定, 検出端の結果から, 軟化 融着帯は指向した形状に移行したことが確認された.

\section{3 試験操業期間中に現われた異常現象}

\section{$4 \cdot 3 \cdot 1$ 連続スリップ}

期間中に Fig. 9 に示すよらな連続スリップの発生し た時期がある.このスリップは小さな送風圧力の変動と 炉頂ガス温度の上昇を伴いながら，ほぼ一定の周期で起 こつた.この原因は Fig. 10 に示すように，通常操業時 に比較して軟化融着带が全体的に低くなり炉中心側に張 り出したことにより，融着帯内側形状と炉芯停滞域との 間隔が狭くなり（Fig.10 中の(A)部）レースウェイヘの コークス供給が不安定になつたためと考えられた。よつ て，指向した軟化融着帯形状を少しゆるめるため， 2 ハ ッチ目のコークスノッチを增加する対策（例えば 52.5 $11 \rightarrow 5311)$ をとり，かつコークス，焼結鉱の常温強度向 


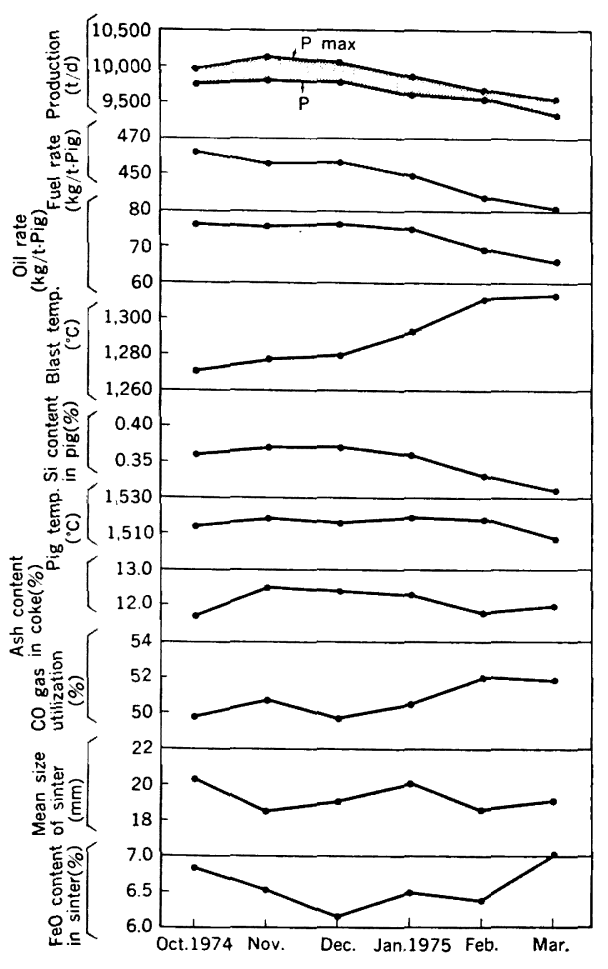

Fig. 6. Operation data of test period

\begin{tabular}{|l|c|c|c|}
\hline \multicolumn{1}{|c|}{ Item } & Period I & Period II & Period III \\
\hline CO gas utilization (\%) & 49.4 & 51.5 & 52.3 \\
Heat loss of upper part of furnace (kcal/t-Pig) & $42 \times 10^{3}$ & $35 \times 10^{3}$ & $37 \times 10^{3}$ \\
Heat loss of lower part of furnace (kcal/t-Pig) & $115 \times 10^{2}$ & $83 \times 10^{3}$ & $86 \times 10^{2}$ \\
Setting point of MA (CCOO) & 5311 & $5311-52.511$ & 52.511 \\
\hline
\end{tabular}

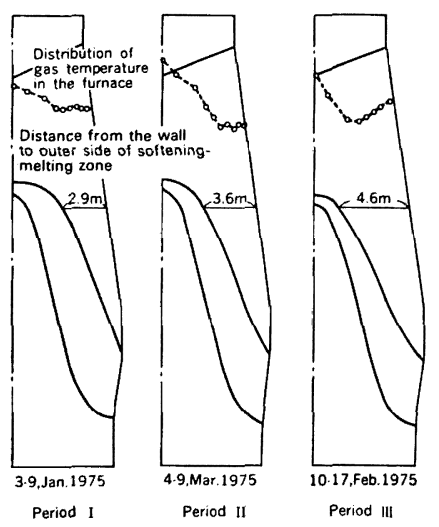

Fig. 7. Estimated pattern of cohesive zone by mathematical model.

上により解消することができた

$4 \cdot 3 \cdot 2$ 円周ハラランスの崩れ

計画に述べた円周ハランス制御を奏施したあと低然料

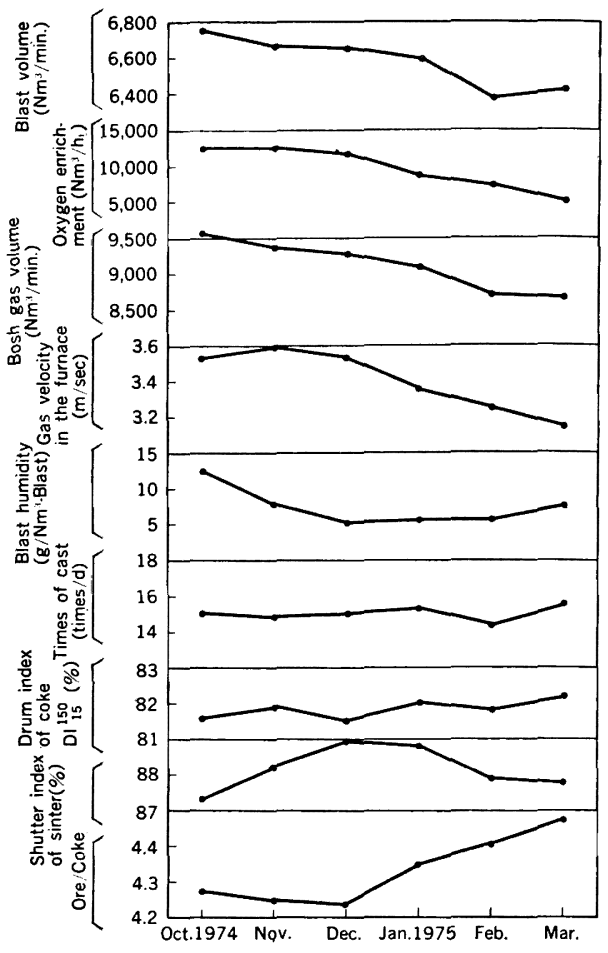

Fig. 6. Operation data of test period.

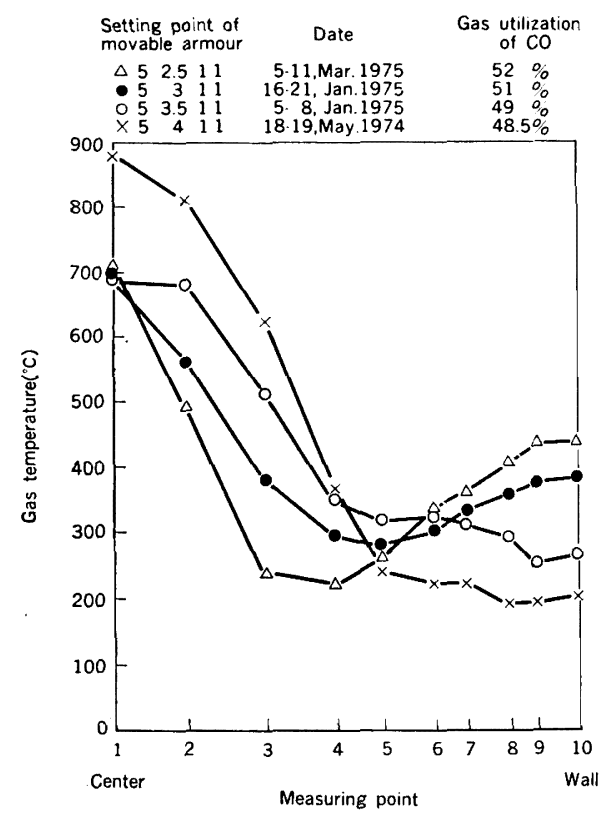

Fig. 8. Distribution of gas temperature in the furnace. 


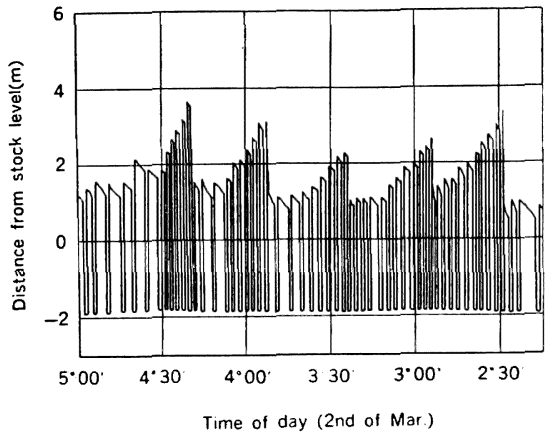

Fig. 9. Descending ${ }^{-}$of burden surface when slips occur intermittently.

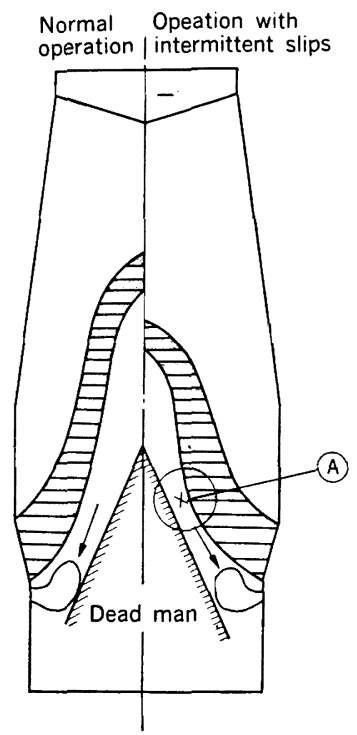

Fig. 10. Estimated condition in normal operation and operation with intermittent slips.

比試験操業に移行したが，Fig. 11 亿示すように円周ハ ランスが崩れ，期間中に 5 回の羽ロごとの重油量調整を 実施した. Fig. 11 中R指数*とは, 円周バランスの崩 れの程度を把握するための指数で，管理基準値として45 を上限としこれより值が高い場合はバランスが崩れてい ると判断した. 低燃料比操業において炉下部融着帯形状 が低下し極限に近づいたとき，羽口ごとの重油量調整だ けで円周バランスを行うには限界があると考光られる。

\section{5. 高炉燃料比の限界およびそれを達成する ための対策}

高炬の燃料比の検討は従来からいろいろな人々によつ

* 各出銑口ごとに, 日平均值により (溶銃温度 $\left({ }^{\circ} \mathrm{C}\right)+$ 溶銧中 $\mathrm{Si}$ 含有 量 $(\%) \times 200)$ を求め，その最大と最小の差で表わす。

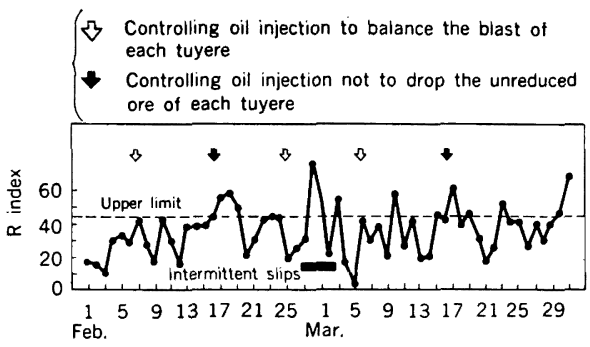

Fig. 11. Circumferential balance in test operation.

て行われているが，ここでは前述した化学工学的モデ ル7により限界燃料比の推定を試みた。

ベース期間として, 君津 3 高炉の昭和 49 年 10 月の 休風日を除いた月平均值をとり，今後到達しらると考兄 られる操業条件を Table 1*のように設定した. Table 1 亿結果を示すが，限界然料比として $\eta_{\mathrm{CO}}=58.8 \%$ に ささえられた $396.5 \mathrm{~kg} / \mathrm{t}-\mathrm{Pig}$ が得られた.

この限界燃料比の基本となる Table 1*の操業条件に ついては，今後の技術改善に負らところが多い，まず送 風温度については, 君津 3 高灯火入れ以来 7 年間の実績 $1270^{\circ} \mathrm{C}$ の例にみられるごとく, 珪石熱風炉の出現によ り耐火物構造としては $1350^{\circ} \mathrm{C}$ に耐觉ると考兄られる. 高温化によつて発生する鉄皮応力腐蝕割れ対策について はまだ若干の検討を残しているが，鉄皮保温技術の確立 により $1350^{\circ} \mathrm{C}$ の送風温度は可能と考无てよい。送風湿 度については近年各社において空気脱湿装置が開発さ れ，当社に敃いてもすで数基の設置をみ，さらに設置 計画が進められて怙り，現実に $\mathrm{lg} / \mathrm{Nm}^{3}$-Blast 送風湿度 操業が行われている.コークス灰分は過去操業において 9\% 前後で品質管理されていたこともあるが，今後の石 炭需給を考え極端な数值の設定をさしひかえ $10 \%$ とし た.

限界燃料比達成への 1 つの課題は原料性状にある. 推 定のための条件として自溶性ペレットを参考にして次の ように設定した。

(1)化学組成 : $\mathrm{T} \cdot \mathrm{Fe}=60 \%, \mathrm{SiO}_{2}=3.8 \%$,

$$
\mathrm{CaO} / \mathrm{SiO}_{2}=1.47 \text { (ヘマタイト鉱石) }
$$

(2) 溶け落ち温度 : $1450^{\circ} \mathrm{C}$

(3)還元率 : $75 \%$ (JIS 法)

(4)平均粒度 : $18 \mathrm{~mm}$

しかし実際には焼結鉱とペレットの間には評価の差があ り，この原因としてペレット使用技術の未確立といら問 題があるが，本質的には粒度に支配される炉内分布の差 異や軟化融着機構に差があると考兄られ，この解決が今 
後の原料技術の中心的課題となると思われる.

さらに限界燃料比操業に打けるもら1つの課題は装入 物の均一降下の保証である.この推定では炉内温度分布 がベース期間とほぼ同じであるが， O/C=4.75 という 高負荷操業下にあつて, 通気性の保証と, 装入物降下安 定のための操業技術の確立と, 均一な高炉プロフィルの 維持が大きなウェイトを占める. そして今後とも, 主と して炉下部の炉内現象についての研究が必要であろう.

\section{6. 結言}

君津 3 高炉において, 高炉の軟化融着帯の制御を主眼 とした低燃料試験操業を計画し（目標 $430 \mathrm{~kg} / \mathrm{t}-\mathrm{Pig}$ ) 試 験操業を実施した結果, 昭和 50 年 3 月に月間平均燃料 比として $431 \mathrm{~kg} / \mathrm{t}-\mathrm{Pig}$ を達成した.

この試験操業の結果にもとづき,さらに燃料比低減の ための技術について検討した結果，今後 10 年間で達成
されるべき限界然料比として約 $400 \mathrm{~kg} / \mathrm{t}-\mathrm{Pig}$ を推定し た.

\section{交献}

1) 研野雄二, 秨岡正毅, 安倍 勲, 久米正一, 天野 箱: 製鉄研究, 288 (1976)， p. 54

2 ) 田阪 興, 金山有治, 奥野嘉雄, 磯山 正：鉄と 鋼, 60 (1974) 4, S 25

3 ) 西田信直, 重見彰利, 斧 勝也, 山口一良: 鉄と 鋼，62 (1976) 11，A95

4 ) 公勝也: “高炉内の軟化溶解帯における反応” (学位諭文), (1978)

5 ) 城塚正, 染谷善晴, 大庭裕共著: 化学装置 (4) 工業物理化学と反応装置, (1963), p. 216 [オー 么社]

6 ) 研野雄二, 須賀田正泰, 安倍 巭, 中村 展: 鉄 と鋼，65 (1979), p.

7 ) 研野雄二, 須賀田正泰, 山口一良：鉄と鋼，65 (1979), p. 